\title{
Nidification of Polybia rejecta (Hymenoptera: Vespidae) associated to Azteca chartifex (Hymenoptera: Formicidae) in a fragment of Atlantic Forest, in the state of Minas Gerais, southeastern Brazil
}

\author{
Marcos Magalhães de Souza ${ }^{1}$, Epifânio Porfiro Pires $^{2,4}$ \& Fábio Prezoto ${ }^{3}$ \\ ${ }^{1}$ Instituto Federal de Educação, Ciência e Tecnologia do Sul de Minas - IFSULDEMINAS, \\ Campus Inconfidentes, CEP 37576-000, Inconfidentes, MG, Brazil \\ ${ }^{2}$ Departamento de Entomologia, Universidade Federal de Lavras - UFLA, \\ CEP 37200-000, Lavras, MG, Brazil \\ ${ }^{3}$ Departamento de Zoologia, Universidade Federal de Juiz de Fora - UFJF, \\ CEP 36036-900, Juiz de Fora, MG, Brazil \\ ${ }^{4}$ Corresponding author: Epifânio Porfiro Pires, e-mail: epifaniopires@yahoo.com.br
}

SOUZA, M.M., PIRES, E.P. \& PREZOTO, F. Nidification of Polybia rejecta (Hymenoptera: Vespidae) associated to Azteca chartifex (Hymenoptera: Formicidae) in a fragment of Atlantic Forest, in the state of Minas Gerais, southeastern Brazil. Biota Neotrop. 13(3): http://www.biotaneotropica.org.br/v13n3/en/ abstract?short-communication+bn02513032013

\begin{abstract}
Records to nesting between associated social wasp Polybia rejecta (Fabricius, 1798) and the ant Azteca chartifex Forel, 1896 in the Parque Estadual do Rio Doce, Minas Gerais, are reported. This association is reported for the first time in this biome. Twelve colonies of $P$. rejecta founded close to nests of $A$. chartifex were observed. The wasp colonies were founded at a distance of about 10-20 cm from the ant nest and they did not overlap. The nests of wasps were smaller compared to ant, but the coloring was similar protective casing, making it difficult to differentiate between the wasp nest and the ant.
\end{abstract}

Keywords: interaction, social wasp, ant, Atlantic Forest, colonies.

SOUZA, M.M., PIRES, E.P. \& PREZOTO, F. Nidificação de Polybia rejecta (Hymenoptera: Vespidae) associada com Azteca chartifex (Hymenoptera: Formicidae) em um fragmento de Mata Atlântica, no estado Minas Gerais, Sudoeste do Brasil. Biota Neotrop. 13(3): http:/www.biotaneotropica.org.br/v13n3/pt/abstract?shortcommunication+bn02513032013

Resumo: Registra-se a nidificação associada entre a vespa social Polybia rejecta (Fabricius, 1798) e a formiga Azteca chartifex Forel,1896 no Parque Estadual do Rio Doce, Minas Gerais. Esta associação é observada neste bioma pela primeira vez. Observaram-se doze colônias de $P$. rejecta fundadas ao lado de ninhos da $A$. chartifex . Cada colônia da vespa social foi fundada a uma distância em torno de 10 a $20 \mathrm{~cm}$ do ninho da formiga, não ocorrendo sobreposição das colônias. Os ninhos das vespas eram menores em relação a formiga, porém a coloração do invólucro protetor era semelhante, o que dificultava a diferenciação entre os ninho da vespa e da formiga.

Palavras-chave: interação, vespa social, formiga, Mata Atlântica, colônias. 


\section{Introduction}

Social wasps are insects that carry out countless ecological functions in ecosystems, acting in biological control, pollination and environmental bioindicators (Prezoto et al. 2005, Souza et al. 2010, Souza \& Zanúncio 2012) and, like any eusocial insect, their survival depends on the success of the foundation of new colonies among other factors (Lima \& Prezoto 2003, Silva et al. 2006, Gobbi et al. 2009).

It is known that ants exerted a selective pressure on the evolution of the architectural standard of wasp nests, due to predation (Andena et al. 2009), and they are considered a threat for Neotropical social wasps (Jeanne 1970).

In spite of the antagonistic relationships between ants and social wasps, they can form interspecific nest associations, as already known for Polybia rejecta (Fabricius, 1798) and Synoeca chalybea Saussure, 1852, which usually build their nests associated to those of ants of the genus Azteca, as recorded in Peru, Costa Rica and Trinidad and Tobago (Vesey-Fitzgerald 1938, Richards 1945, Herre et al. 1986). It has been demonstrated that most of the species of Vespidae nest on plants that possibly possess substances repellent to ants, and that nesting associated to ants represents $11.5 \%$ of the total recorded in French Guiana (Corbora et al. 2009). Association of wasp nests with ants of the genus Azteca can be one of the few defenses tropical wasps have against invasions by ants of the tribe Ecitonini (Richards \& Richards 1951).

The relationships between wasps and Azteca ants can also be competitive, as recorded for wasps in the genera Polybia (Fry, 1972) and Charterginus Fox, 1898, which were observed stealing food from Azteca ants in French Guiana and Costa Rica (LaPierre et al. 2007). In the Brazilian Amazon also no record of the association between social wasps Polybia rejecta and Synoeca virginea (Fabricius, 1804) and the ant Azteca chartifex (Somavilla et al. 2013).

Nidification is an important aspect for better understanding the role of those insects in natural ecosystems (Dejean et al. 1998, Hunt $\&$ Carpenter 2004), and there is little information on social wasps nesting in the Atlantic Forest, a fragmented biome with strong human influence, and considered a biodiversity "hotspot" (Myers et al. 2000).

The objective of this study was to report the nesting association between the social wasp P. rejecta and the ant Azteca chartifex Forel, 1896 in Parque Estadual do Rio Doce, the largest Atlantic Forest reserve in the state of Minas Gerais, Brazil.

\section{Material and Methods}

The study was conducted in Parque Estadual do Rio Doce, the largest remnant of Atlantic Forest in Minas Gerais (36.970 hectares), inserted in the municipalities of Marliéria, Timóteo and Dionísio $\left(19^{\circ}\right.$ $45^{\prime}$ to $19^{\circ} 30^{\prime} \mathrm{S}$ and $42^{\circ} 38^{\prime}$ to $\left.48^{\circ} 28^{\prime} \mathrm{W}\right)$. The average climate is hot and humid, with two well defined seasons: a dry and moderately cold season, with temperatures ranging from 7 to $20^{\circ} \mathrm{C}$, and a hot and humid season, with temperatures ranging from 28 to $39{ }^{\circ} \mathrm{C}$. The precipitation varies from 1350 to $1900 \mathrm{~mm}$ annually and the altitude ranges between 236 and 515 m (Instituto... 1994, Nemésio \& Silveira 2006).

The records of the associations were made from January to December, 2010. On this period it was performed 20 observations. An active search method was employed to record the colonies, which consists of walking trails for present inside and edge of woods, watching the treetops, roots of epiphytes, broadleaf, ravines and rocky outcrops (Souza \& Prezoto 2006). The number of associated colonies and the distance between nests was obtained with the aid of binoculars and naked eye. There was a high activity of the individuals at the moment the observations and the collection of individuals which was intentional, in order to perform observations during 15 to 20 minutes for each colony, by using the ad libitum method, recording all behavioral activities (Del-Claro 2010). By using this methodology we were able to observe aggressiveness behavior between wasps and ants. Ant identification was made at the entomology laboratory of the Universidade Federal de Viçosa, state of Minas Gerais, Brazil. Identifications of social wasps were carried out at the Museu Paraense Emíllio Goeldi, in Belém, state of Pará, Brazil, where the collected biological material has been deposited.

\section{Results and Discussion}

Twelve $P$. rejecta colonies were recorded, all of them founded close to nests of the ant A.chartifex (Figure 1), a novel record for the Atlantic Forest in Brazil, so far only reported in the Brazilian Amazon (Somavilla et al. 2013).

Each wasp colony was founded at a distance of around 10 to $20 \mathrm{~cm}$ from the ant nest, with no colony overlap.The nests of wasps were smaller compared to ant, but the coloring was similar protective casing, making it difficult to differentiate between the wasp nest and the ant, difficulting recognition by an observer, even at a distance of ten meters. No other association was observed, the relationships between the wasps and the ants were not appraised through experiment, which may be due to the short time of observations.

All the observed nests of $P$. rejecta were associated to $A$. chartifex, however, some nests of the ant were isolated, suggesting that the wasp obtains greater benefits from the association. This association with ants was not observed in any of the other 35 species of social wasps identified in the study area. The protection against mammalian predators of ants, as anteaters, to be the highest benefit for the ant, and $P$. rejecta can offer protection against anteaters, thus preventing damage to the nests of Azteca. Therefore, the social wasps do not cause damage to the ants and can take advantage of their good tolerance (Jeanne 1972, Herre et al. 1986).

The association of $P$. rejecta nesting close to nests of $A$. chartifex showed to be common in this area of Atlantic Forest. There was no record of any aggression between both species. However it was not analyzed the potential benefits of this interspecific relationship. Thus, further specific ethological studies should be performed to assess whether this relationship is only a tolerance of the ant to the wasp, or if there is any kind of symbiosis between them.

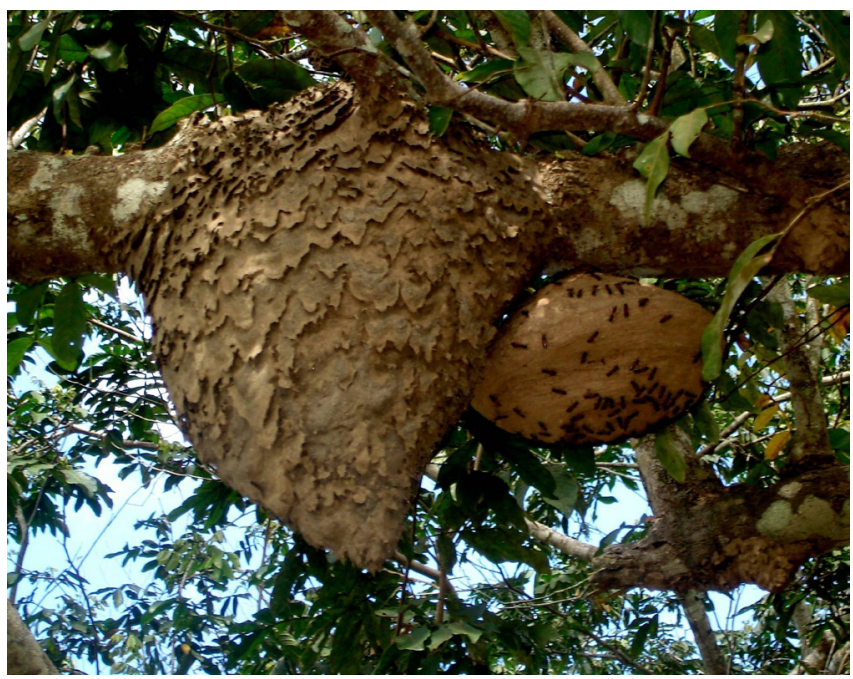

Figure 1. Associated nests of the wasp Polybia rejecta (right) and the ant Azteca chartifex (left) in Parque Estadual do Rio Doce, Minas Gerais, Brazil. 


\section{References}

ANDENA, S.R., CARPENTER J. M. \& NOLL, F.B. 2009. A phylogenetic analysis of Synoeca de Saussure, 1852, a neotropical genus of social wasps (Hymenoptera: Vespidae: Epiponini). Entomol. Am. 115(1):81-89.

CORBORA, B., CARPENTER, J.M., CÉRÉGHINO, R., LEPONCE, M., GIBERNAU, M. \& DEJEAN, A. 2009. Diversity and nest site selection of social wasps along Guianese forest edges: assessing the influence of arboreal ants. C. R. Biol. 332(5):470-479. PMid:19393979. http://dx.doi. org/10.1016/j.crvi.2009.01.003

DEJEAN, A., CORBARA, B. \& CARPENTER, J.M. 1998. Nesting site selection by wasps in the Guianese rain forest. Insectes Soc. 45 (1):33-41. http://dx.doi.org/10.1007/s000400050066

DEL-CLARO, K. 2010. Introdução a Ecologia Comportamental, um manual para o estudo do comportamento animal. 2. ed. Technical Books, Rio de Janeiro, v.1, 128p.

GOBBI, N., GOVONE, J.S., PINTO, N.P.O. \& PREZOTO, F. 2009. Produtividade em colônias de Polistes (Aphanilopterus) versicolor Olivier, 1791 (Hymenoptera: Vespidae, Polistinae). Rev. Bras. Zoocienc. 11(3):191-199.

HERRE, E.A., WINDSOR, D.M. \& FOSTE, R.B. 1986. Nesting associations of wasps and ants on lowland Peruvian ant-plant. Psyche 93(1):321-330. http://dx.doi.org/10.1155/1986/94501

HUNT, J.H. \& CARPENTER, J.M. 2004. Intra-specific Nest Form Variation in Some Neotropical Swarm-founding Wasps of the Genus Parachartergus (Hymenoptera: Vespidae: Epiponini). J. Kans. Entomol. Soc. 77(4):448456. http://dx.doi.org/10.2317/E-26.1

INSTITUTO ESTADUAL DE FLORESTAS - IEF. 1994. Pesquisas prioritárias para o Parque Estadual do Rio Doce, Brasil. IEF, Belo Horizonte, 35p.

JEANNE, R.L. 1970. Chemical Defense of Brood by a Social Wasp. Science 168(3938):1465-1466. PMid:5445937. http://dx.doi.org/10.1126/ science.168.3938.1465

JEANNE, R.L. 1972. The social Biology of Neotropical wasp Mischocyttarus drewsenii. Bull. Mus. Comp. Zool. 144(3):63-150.

LAPIERRE, L., HESPENHEIDE, H. \& DEJEAN, A. 2007. Wasps robbing food from ants: a frequent behavior? Naturwissenschaften 94(1):9971001. PMid:17546437. http://dx.doi.org/10.1007/s00114-007-0270-y

LIMA, M.A.P. \& PREZOTO, F. 2003. Foraging activity rhythm in the Neotropical swarm-founding wasp Polybia platycephala sylvestris (Hymenoptera: Vespidae) in different seasons of the year. Sociobiology 42(3):745-752.
MYERS, N., MITTERMEIER, R.A., MITTENMEIER, C.G., FONSECA, G. A. B. \& KENT, J. 2000. Biodiversity hotspots for conservation priorities. Nature 403(1):853-858. PMid:10706275. http://dx.doi. org/10.1038/35002501

NEMÉSIO, A. \& SILVEIRA, F. A. 2006. Edge effects on the orchid-bee fauna (Hymenoptera: Apidae) at a large remnant of Atlantic Rain Forest in southeastern Brazil. Neotrop. Entomol. 35(3):313-323. PMid:18575690. http://dx.doi.org/10.1590/S1519-566X2006000300004

PREZOTO, F., LIMA, M.A.P. \& MACHADO V. L.L. 2005. Survey of Preys Captured and Used by Polybia platycephala (Richards) (Hymenoptera: Vespidae, Epiponini). Neotrop. Entomol. 34(5):849-851. http://dx.doi. org/10.1590/S1519-566X2005000500019

RICHARDS, O.W. 1945. A Revision of the Genus Mischocyttarus de Saussure (Hymen., Vespidae). Trans. R. Entomol. Soc. Lond. 95(7):295-462. http:// dx.doi.org/10.1111/j.1365-2311.1945.tb00264.x

RICHARDS, O.W. \& RICHARDS, M.J. 1951. Observations on the Social Wasps of South America (Hymenoptera,Vespidae). Trans. R. Entomol. Soc. Lond. 102(1):1-170. http://dx.doi.org/10.1111/j.1365-2311.1951. tb01241.x

SILVA, C.A.D., PIRES, E.M., LACERDA, M.C., PREZOTO, F., ZANUNCIO, J.C. \& SERRÃO, J.E. 2006. Immature stages and nest characteristics of Apoica pallens (Hymenoptera, Vespidae). Sociobiology 48(2):365-374.

SOMAVILLA, A.; FERNANDES, I. O.; OLIVEIRA, M. L. \& SILVEIRA, O. T. 2013. Association among wasps' colonies, ants and birds in Central Amazonian. Biota Neotrop. 13(2):1-6. http://dx.doi.org/10.1590/S167606032013000200031

SOUZA, M.M. \& PREZOTO, F. 2006. Diversity of social wasps (Hymenoptera, Vespidae) in Semideciduous forest and cerrado (savanna) regions in Brazil. Sociobiology 47(1):135-147.

SOUZA, M.M., LOUZADA, J., SERRAO, J.E. \& ZANUNCIO, J.C. 2010. Social wasps (Hymenoptera: Vespidae) as indicators of conservation degree of riparian forests in southeast Brazil. Sociobiology 56(1):1-10.

SOUZA, M.M. \& ZANUNCIO, J.C. 2012. Marimbondos - Vespas sociais (Hymenoptera: Vespidae). Editora UFV, Viçosa, 79p.

VESEY-FITZGERALD, D. 1938. Social Wasps (Hymenoptera: Vespidae) from Trinidad, with a note on the genus Trypoxylon Latreille. Trans. R. Entomol. Soc. Lond. 87(1):181-191. 